\title{
Characterization of an extinct seabird colony on the island of Santa Luzia (Cabo Verde) and its potential for future recolonizations
}

\author{
Maria Alho ${ }^{1} \mathbb{D} \cdot$ José Pedro Granadeiro ${ }^{2} \cdot$ Juan Carlos Rando ${ }^{3} \cdot$ Pedro Geraldes $^{4} \cdot$ Paulo Catry $^{1}$
}

Received: 13 March 2021 / Revised: 23 July 2021 / Accepted: 3 August 2021

(c) Deutsche Ornithologen-Gesellschaft e.V. 2021

\begin{abstract}
Islands worldwide have suffered seabird extinctions after the arrival of humans and the alien species they introduced. On Santa Luzia (Cabo Verde), an uninhabited island of $35 \mathrm{~km}^{2}$, the presence of an impressive quantity of petrel bones in coastal dunes suggested the previous existence of an important seabird colony. Yet, these remains had not been identified and no seabird extinctions have been reported for the island. This paper characterizes the extinct seabird colony of Santa Luzia and discusses the chronology and possible causes of its demise. A total of 130 grid points in a $5 \mathrm{~km}^{2}$ area and 38 supplementary points within and outside the main study area were excavated to collect bone remains. A total of 1318 anatomical elements, identified as White-faced Storm Petrel Pelagodroma marina eadesorum (85.3\% of the minimum number of individuals, MNI), Boyd's Shearwater Puffinus lherminieri boydi (11.8\% MNI) and Cape Verde Storm Petrel Hydrobates jabejabe (2.9\% $\mathrm{MNI}$ ), were found in $18 \%$ of the sampling points, within $1.25 \mathrm{~km}^{2}$. Neither of the two former species currently breeds on Santa Luzia. In addition, two bones of the Cape Verde Shearwater Calonectris edwardsii and Pterodroma sp. were detected in the supplementary points. Radiocarbon dating of White-faced Storm Petrel $(n=10)$ and Boyd's Shearwater bones $(n=13)$ suggests that the colony probably went extinct during the first half of the twentieth century. The recent extinction of these species on Santa Luzia might be consequent on the arrival of humans and their domestic animals on the island. We estimate that the extinct seabird populations must have been at least hundreds of thousand strong, far larger than current populations of the same species in Cabo Verde. We suggest that, following feral cat eradication, Santa Luzia has a significant potential for seabird restoration.
\end{abstract}

Keywords Bones $\cdot$ Fossils $\cdot$ Radiocarbon $\cdot$ Petrel $\cdot$ Cape Verde $\cdot$ Extinction

\section{Zusammenfassung}

Beschreibung einer erloschenen Seevogelkolonie auf der Insel Santa Luzia (Kap Verde) und deren Potenzial für zukünftige Wiederansiedlungen

Weltweit kam es auf Inseln nach der Ankunft des Menschen und den durch diesen eingeführten fremden Arten zum Aussterben von Seevögeln. Auf Santa Luzia (Kap Verde), einer $35 \mathrm{~km}^{2}$ großen unbewohnten Insel, deutet das Vorhandensein einer beeindruckenden Menge an Sturmvogelknochen in den Küstendünen auf die ehemalige Existenz einer bedeutenden Seevogelkolonie hin. Bislang waren diese Funde aber noch unbestimmt, und es waren keine Aussterbeereignisse von Seevögeln von dieser Insel bekannt. In diesem Beitrag beschreiben wir die erloschene Seevogelkolonie auf Santa Luzia und diskutieren Chronologie und mögliche Ursachen ihres Verschwindens. An insgesamt 130 Rasterpunkten in einem 5

Communicated by C. Barbraud.

Maria Alho

maria.s.alho@gmail.com

1 Marine and Environmental Sciences Centre (MARE), ISPA-Instituto Universitário, Rua Jardim do Tabaco 34, 1149-041 Lisbon, Portugal

2 Centro de Estudos do Ambiente e do Mar (CESAM), Departamento de Biologia Animal, Faculdade de Ciências da Universidade de Lisboa, 1749-016 Lisboa, Portugal

3 Departamento de Biologia Animal, Edafología y Geología, Universidad de La Laguna Tenerife, Canary Islands, San Cristóbal de la Laguna, Spain

4 SPEA-Sociedade Portuguesa Para o Estudo das Aves, Av. Columbano Bordalo Pinheiro, $873^{\circ}$ Andar, 1070-062 Lisboa, Portugal 
$\mathrm{km}^{2}$ großen Gebiet sowie an 38 Zusatzpunkten inner- und außerhalb des Hauptuntersuchungsgebietes wurden Grabungen durchführt und Knochenfunde gesammelt. An 18\% der Grabungspunkte wurden innerhalb eines Gebietes von 1,25 km² insgesamt 1318 anatomische Elemente gefunden, welche als Weißgesicht-Sturmschwalbe Pelagodroma marina eadesorum (85,3\% der Mindestindividuenzahl; engl.: minimum number of individuals, MNI), Boydsturmtaucher Puffinus lherminieri boydi (11,8\% MNI) und Kapverden-Wellenläufer Hydrobates jabejabe (2,9\% MNI) bestimmt wurden. Keine der beiden erstgenannten Arten brütet gegenwärtig auf Santa Luzia. Des Weiteren wurden an den Zusatzpunkten zwei Knochen des Kapverden-Sturmtauchers Calonectris edwardsii beziehungsweise von Pterodroma sp. entdeckt. Die Radiokarbondatierung der Knochen von Weißgesicht-Sturmschwalbe $(n=10)$ und Boydsturmtaucher $(n=13)$ legt nahe, dass die Kolonie vermutlich während der ersten Hälfte des 20. Jahrhunderts erlosch. Das rezente Aussterben dieser Arten auf Santa Luzia könnte die Folge der Ankunft von Menschen und ihrer Haustiere auf der Insel sein. Wir schätzen, dass die erloschenen Seevogelpopulationen wenigstens hunderttausende Individuen umfassten, also weit mehr als die gegenwärtigen Populationen derselben Arten auf den Kapverden. Wir sind der Meinung, dass Santa Luzia nach erfolgter Entfernung verwilderter Katzen ein signifikantes Potenzial für die Wiederansiedlung von Seevögeln besitzt.

\section{Introduction}

Over the last centuries, largely following the Polynesian expansion and later European expeditions, many seabird species have suffered from population declines or been lost completely (Steadman 2006). Islands worldwide often accommodate large seabird colonies (Belopol'skii 1957; Pearson 1968; Croxall and Prince 1980; Hunter et al. 1982), and palaeornithological studies suggest that the majority of seabird extinctions have occurred in insular ecosystems (Olson and James 1982; Quammen 1996; Worthy and Holdaway 2002; Steadman 2006; Rando and Alcover 2008 , 2010). Seabirds are particularly vulnerable to humaninduced alterations, such as habitat destruction, hunting and introduced predators (Croxall et al. 2012; Dias et al. 2019). The loss of seabird species during the Holocene has involved more than 20 documented extinctions on islands around the world (Steadman 2006; Scofield 2009; Tyrberg 2009), with many more probably having gone unnoticed. All these insular declines and extinctions seem to have been associated with the arrival of humans and subsequent alterations (Blackburn et al. 2004; Croxall et al. 2012).

Seabird fossils and subfossils are an important but poorly exploited resource, useful for understanding the long-term history of populations and communities, and the interpretation of biogeographical patterns and structure of modernday communities. Fossils can provide information on cooccurring species during a specific period of time and in a specific area (Steadman and Olson 1985; Warheit 2002; Steadman 2006), on the original species composition of a region, and may also contribute to a broader understanding of past environments and ecological interactions (Steadman 2006). Fossil assemblages of extinct birds can also guide local actions to restore ecosystem function and processes through reintroductions (Barnosky et al. 2017; Wood et al. 2017).

Macaronesia is a group of five archipelagos of the northeastern Atlantic Ocean-Cabo Verde, the Canary Islands,
Selvagens, Madeira and the Azores—where similar seabird assemblages are found (Monteiro et al. 1996). Several seabird fossils from these archipelagos have been documented (Pieper 1985; Alcover and McMinn 1995; Monteiro et al. 1996; Rando and Alcover 2008, 2010), but only one study referred to Cabo Verde, on the island of Sal (Boessneck and Kinzelbach 1993). On the Canary Islands, the fossil record indicates that a significant part of the original community of Procellariiformes has disappeared, with three species confirmed extinct so far (McMinn et al. 1990; Walker et al. 1990; Rando 2002; Rando and Alcover 2008, 2010).

Radiocarbon dating of extracted collagen of two extinct seabirds from the Canary Islands has allowed to establish an approximate date for their extinctions. One of these extinctions was probably associated with the arrival of aboriginal populations to the islands, and the other happened in the fourteenth century, coinciding with the arrival of Europeans (Rando and Alcover 2008, 2010).

Over the last 500 years, the native wildlife of the Cabo Verde archipelago suffered major declines and some extinctions, with seabirds being no exception (Hazevoet 1995). Cabo Verde is currently home to eight species of breeding seabirds, three of which are endemic (Hazevoet 2001; Semedo et al. 2020). Humans have exploited these populations for centuries, leading to drastic declines. The main colonies today exist only in largely inaccessible areas and it is likely that present seabird populations in Cabo Verde are mere remnants of much richer ones, both in diversity and numbers (Hazevoet 2001; Semedo et al. 2020).

The island of Santa Luzia, situated in the north of the Cabo Verde archipelago, presents an extensive area of dunes where many unidentified seabird subfossils are partially buried (e.g. Mateo 2012), suggesting the past existence of an important seabird colony. At the moment, only one species of seabird occurs on the island, the Cape Verde Storm Petrel Hydrobates jabejabe (Olivera et al. 2013).

The Cabo Verde Islands were colonized by the Portuguese in 1462 (Costa 1939; Verlinden 1963). Although uninhabited 
in the present day, Santa Luzia has seen human activity since the early fifteenth century and remained sparsely populated until the second half of the nineteenth century (Costa 1939; Mateo 2012). Along with the attempts of colonization came other alien mammals, such as dogs Canis familiaris, goats Capra hircus, domestic cats Felis catus and the house mouse Mus musculus, probably introduced to Santa Luzia when the first herdsmen settled there, during the eighteenth century. Until the mid-1960s, Santa Luzia was sporadically inhabited by shepherds and goat herders and temporarily visited by fishermen from neighboring islands (Bebiano 1932; Diniz and Matos 1994).

This paper aims to present the first detailed description of the current distribution of the seabird subfossil remains on Santa Luzia, the species composition and to estimate the likely period of extinction using radiocarbon dating. These data are used to discuss the likely causes of extinction and the relevance of deploying efforts to restore this island for breeding seabirds.

\section{Methods}

\section{Study site and sampling}

The island of Santa Luzia $\left(16^{\circ} 45^{\prime} 41^{\prime \prime} \mathrm{N}, 24^{\circ} 45^{\prime} 38^{\prime \prime} \mathrm{W}\right)$ has an approximate area of $35 \mathrm{~km}^{2}$ (Fig. 1). The climate is desertlike and the vegetation is sparse. The island is characterized by stony plains, sand dunes and small mountain massifs (maximum altitude is $395 \mathrm{~m}$ ).

Fieldwork was carried out in September 2018. The study area was selected based on preliminary field observations, where abundant seabird bones are present. The selected study area consists of a clearly delimited area of mobile dunes, with sandy sediments of predominantly marine origin carried by the prevailing trade winds, plus a buffer zone of ca. 100-150 m (Fig. 1). The total area covers approximately $5 \mathrm{~km}^{2}$. To carry out a systematic survey over the study area, we defined a regular (diagonal) grid comprising 130 points separated from each other by $200 \mathrm{~m}$, marked with a handheld GPS. At each sampling point, a quadrat of $1 \mathrm{~m}^{2}$ was set on the ground and all bone remains were collected by hand at the surface level, and carefully stored in plastic containers

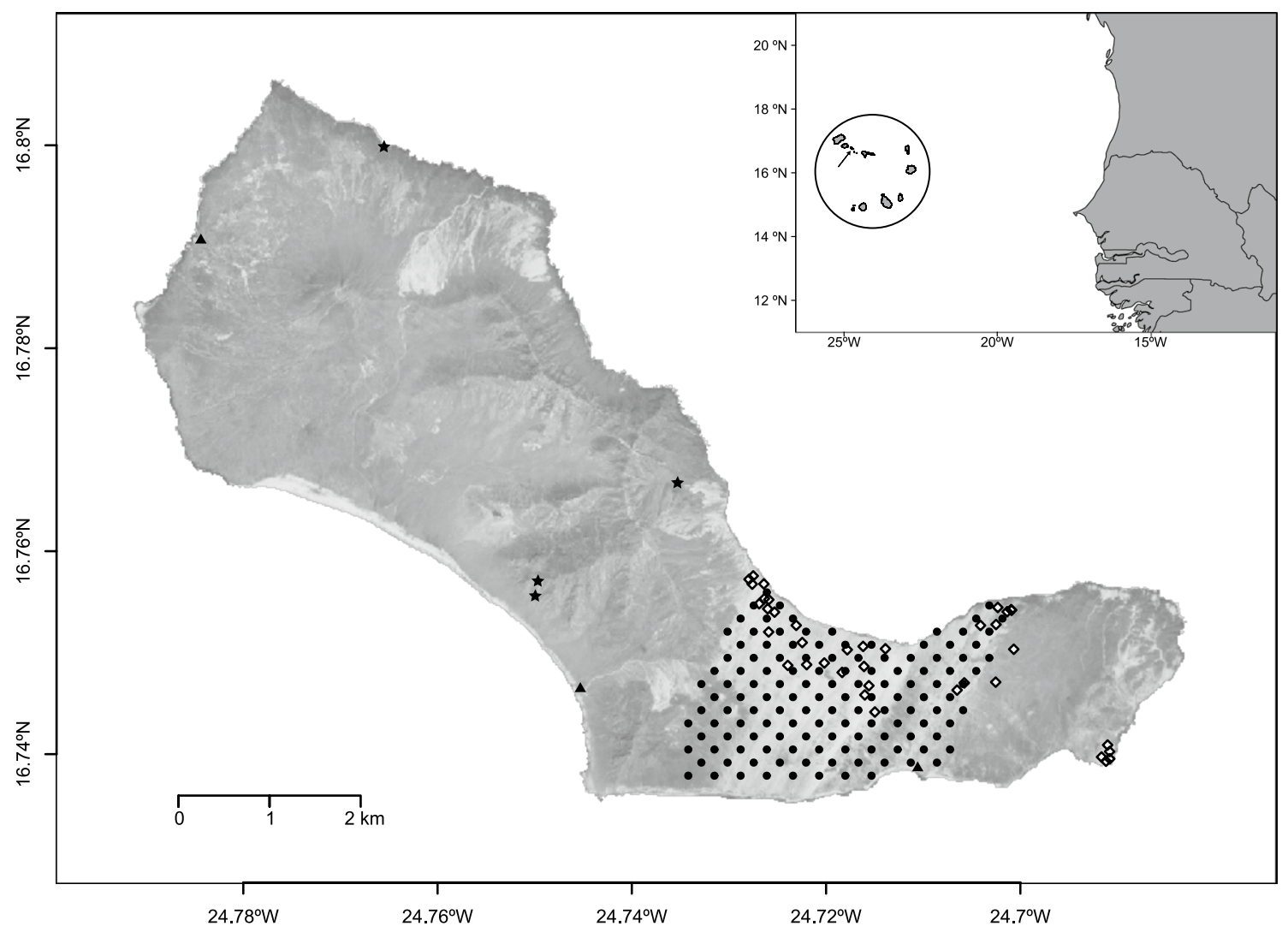

Fig. 1 Map of Santa Luzia. Inset: the position of Santa Luzia within Cabo Verde Islands. Circles represent study points sampled within a pre-defined grid and diamonds represent the supplementary sampling points within and outside the study area. Stars represent the probable nesting sites of Cape Verde Storm Petrel on Santa Luzia. Fishermen camps are represented with a black triangle 
filled with soft cotton, until analysis. Anatomical elements that were broken beyond recognition were discarded. Wherever bones were present at the surface, we carefully dug $15 \mathrm{~cm}$ deep into the sediment to prospect for the presence of more sub-fossils in deeper layers, but none were ever found.

Bones were identified using the osteological reference collection at the Archaeosciences Laboratory (LARC, Ministry of Culture, Portugal), and the vertebrates' collection of the Department of Geology, Edaphology and Animal Biology of La Laguna University (DZUL). We also used our own reference collection prepared from bones of seabird species present on the island of Selvagem Grande, Madeira. We identified the laterality of the anatomical elements and quantified each anatomical element for each species at every sampling point. We then identified the first and second most frequent anatomical element for each species encountered over the entire study area for estimates of species abundance. To prevent overestimation of the number of individuals, ribs, vertebrae and phalanges were not included in the analysis. Species abundance was quantified based on the Number of Identified Specimens (NISP), where specimens refers to anatomical elements, with the Minimum Number of Individuals (MNI) of each species estimated as the number of the most frequently observed bone type of a given laterality.

Estimates of the number of adult birds of each species for the entire area were determined as the mean of the MNI (or NISP, in items per $\mathrm{m}^{2}$ ) obtained at all sampling points, and then multiplied by the total studied area. To establish confidence intervals for the estimated parameters, we used a bootstrap procedure (Efron and Gong 1983), resampling the number of bones found in each square 10,000 times (with replacement). The $95 \%$ confidence intervals were calculated by the percentile method, i.e., by selecting the 2.5 and $97.5 \%$ quantiles of the average number of bones obtained in each bootstrap iteration (Crowley 1992). All analyses were conducted in the R 3.5.0 environment ( $R$ Core Team 2020).

In addition to the grid sampling, we also carried out a series of supplementary sampling points within and outside the study area to check for the presence of additional species represented in the subfossils and to detect any additional areas with significant bone deposits. Counts from these supplementary points were not included in the estimation of NISP or MNI for the area (see Electronic Supplementary Information Table $\mathrm{S} 1$ ).

Many bones of seabird nestlings were also present in the study area but only the bones of adult birds were considered. The bones of chicks can be easily identified since they are smaller in size and are not yet ossified in their proximal and distal epiphyses. The latter phenomenon makes it impossible to determine the laterality of the anatomical elements and to identify them. Additionally, they are often more fragile and suffer more fragmentation.

\section{Radiocarbon dating}

Thirteen humeri of Boyd's Shearwater Puffinus lherminieri boydi and ten tibiotarsi of White-faced Storm Petrel Pelagodroma marina eadesorum were selected for radiocarbon analysis to estimate their age. The collagen of the bones was extracted and directly dated for radiocarbon $\left({ }^{14} \mathrm{C}\right)$ by accelerator mass spectrometry (AMS) at the at the Keck Carbon Cycle AMS Laboratory at the University of California, Irvine, using standard procedures (Longin 1971; Brown et al. 1988).

Radiocarbon samples from species that obtain their carbon from a source (or reservoir) different from atmospheric carbon, such as seabirds, will yield radiocarbon dates that are overestimated by about 400 radiocarbon years compared to a bone from a terrestrial ecosystem (Stuiver and Braziunas 1993). Therefore, a reservoir correction must be made to any conventional marine dates to account for this difference.

Radiocarbon data were calibrated using the program OxCal 4.4 (Bronk Ramsey 2009), the marine calibration curve Marine20 (Heaton et al. 2020) with a regional correction, or $\Delta \mathrm{R}$, of $70 \pm 70$, obtained from marine samples (mollusk shells) and terrestrial samples (goat bones) from São Vicente Island, Cabo Verde Archipelago (Monge Soares et al. 2011). Calibrated calendar ages derived from the radiometric results are reported here as years CE (Current Era). Calibrated radiocarbon dates are expressed as $2 \sigma$ intervals (i.e., $P=95.45 \%$ ) indicating that the true age of the dated material is more recent than the lower limit value of the $2 \sigma$ interval and independently, it is older than the upper limit value of the $2 \sigma$ interval (e.g. Zilhão 2001; Ramis et al. 2002; Rando and Alcover 2008). That is, if the calibrated age of a sample is $644-1010 \mathrm{CE}$, the true age of the sample is more recent than the year $644 \mathrm{CE}$ but older than the year $1010 \mathrm{CE}$ with a probability of $95.45 \%$.

We applied an optimal linear estimation method (Roberts and Solow 2003; Solow 2005; Clements et al. 2013) to the lower limits of the $2 \sigma$ intervals obtained from calibration, using these data like sighting records to approach, in a conservative way, to the extinction year of the bird colony. Confidence intervals (i.e., 95\% CI) were calculated using R 3.5.0 (R Core Team 2020) and the package "sExtinct" (Clements 2013).

In addition, we used the Bayesian radiocarbon calibration software BCal (Buck et al. 1999; Buck and Bard 2007) to calculate the probability that a given year is contained between the lower and upper temporal bounds of the dated samples. 


\section{Results}

\section{Taxonomic composition of the seabird assemblage}

All sub-fossils were found on the surface of the dunes, with no further remains being found after digging into the sediment (Fig. 2). We found no visible stratigraphy. Of the 130 quadrats sampled, $10(8 \%)$ contained seabird bones and 21 (16\%) had fragments of eggshells (Fig. 3). A total of 407 bone remains were collected and examined, resulting in at least 136 individuals of three species of Procellariformes: White-faced Storm Petrel, Boyd's Shearwater and Cape Verde Storm Petrel Hydrobates jabejabe. Whitefaced Storm Petrel was the most abundant and widespread seabird in the assemblage, with a MNI of 116, estimated from tarsometatarsi and tibiotarsi. Boyd's Shearwater was also well distributed but found in lower numbers (Fig. 3, Table 1), with a MNI of 16 and Cape Verde Storm Petrel was represented by 4 bones, each corresponding to a different individual (Fig. 3, Table 1).

The estimated number of adult birds represented in bone remains for the study area was 4,600,000 (95\%
CI 1,720,000-8,200,000) for White-faced Storm Petrel, 640,000 (95\% CI 200,000-1,200,000) for Boyd's Shearwater and 160,000 (95\% CI 0-440,000) for Cape Verde Storm Petrel.

The supplementary sampling points provided two bones of both Cape Verde Shearwater Calonectris edwardsii and a gadfly petrel Pterodroma sp. (MNI $=1$ in each case). The latter bones probably correspond to Cape Verde Petrel Pterodroma feae, but the small sample prevented their identification with full confidence.

In addition to seabird remains, we also found three mandibles of the extinct Cape Verde giant skink Chioninia cocte $i$ within the grid sampling.

\section{Radiocarbon dating}

Calibrated ages are shown in Table 2 (and Electronic Supplementary Information Fig. S1). Most dates fell inside the II millennium CE, only two samples $(224,289$ and 222,713 ) showed both limits of $2 \sigma$ calibration interval in the I millennium. In all the samples of White-faced Storm Petrel and seven of the samples of Boyd's Shearwater the
Fig. 2 Images of the seabird subfossils from dune deposits in Santa Luzia, Cabo Verde. Bottom: Egg and skull of Whitefaced Storm Petrel

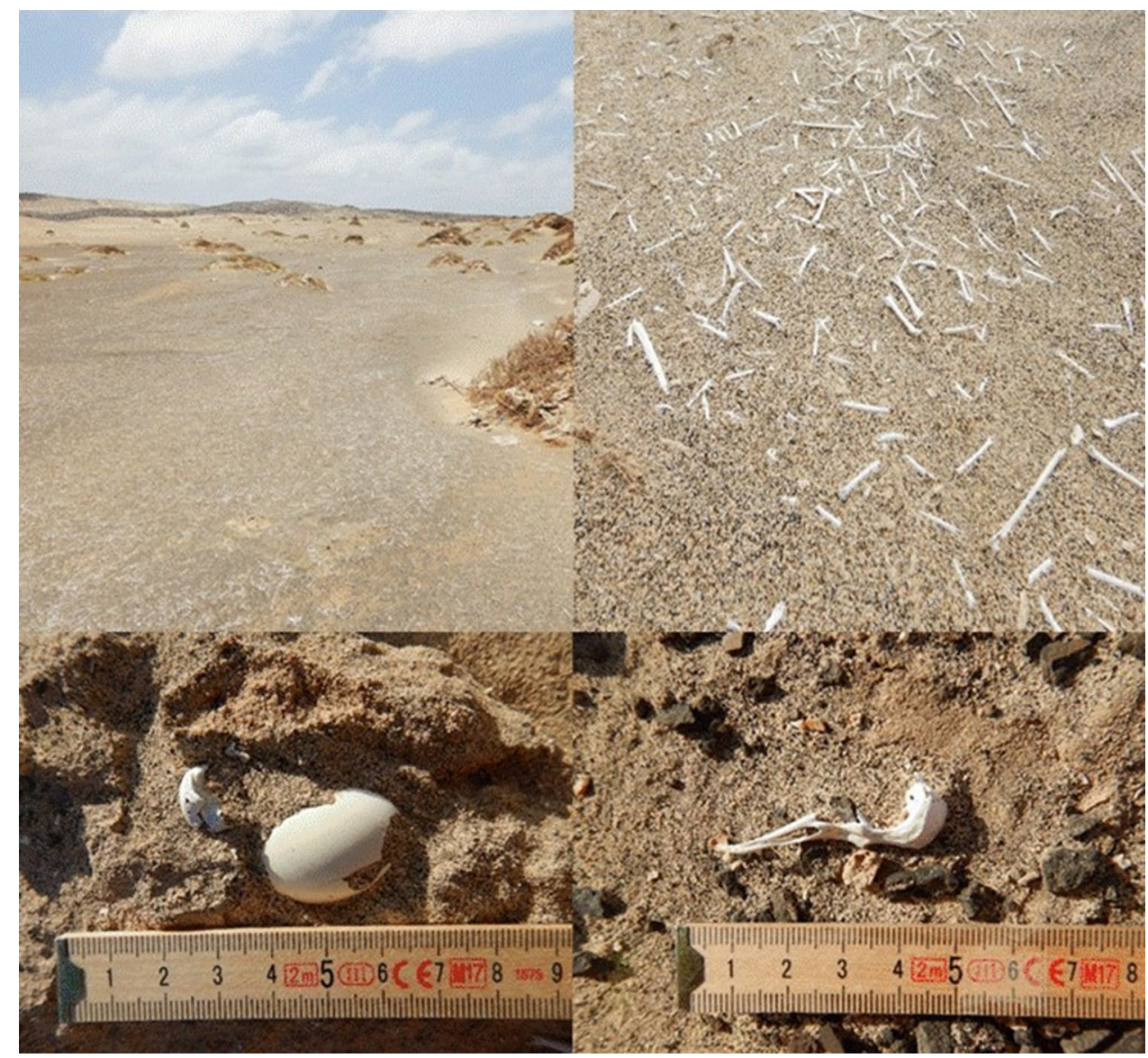


Fig. 3 Species abundance in terms of MNI (minimum numbers of individuals) of White-faced Storm Petrel, Boyd's Shearwater and Cape Verde Storm Petrel from the bird bone assemblage collected in the dunes of Santa Luzia, Cabo Verde. Circles represent study points sampled within a pre-defined grid and triangles represent the supplementary sampling points within and outside the study area
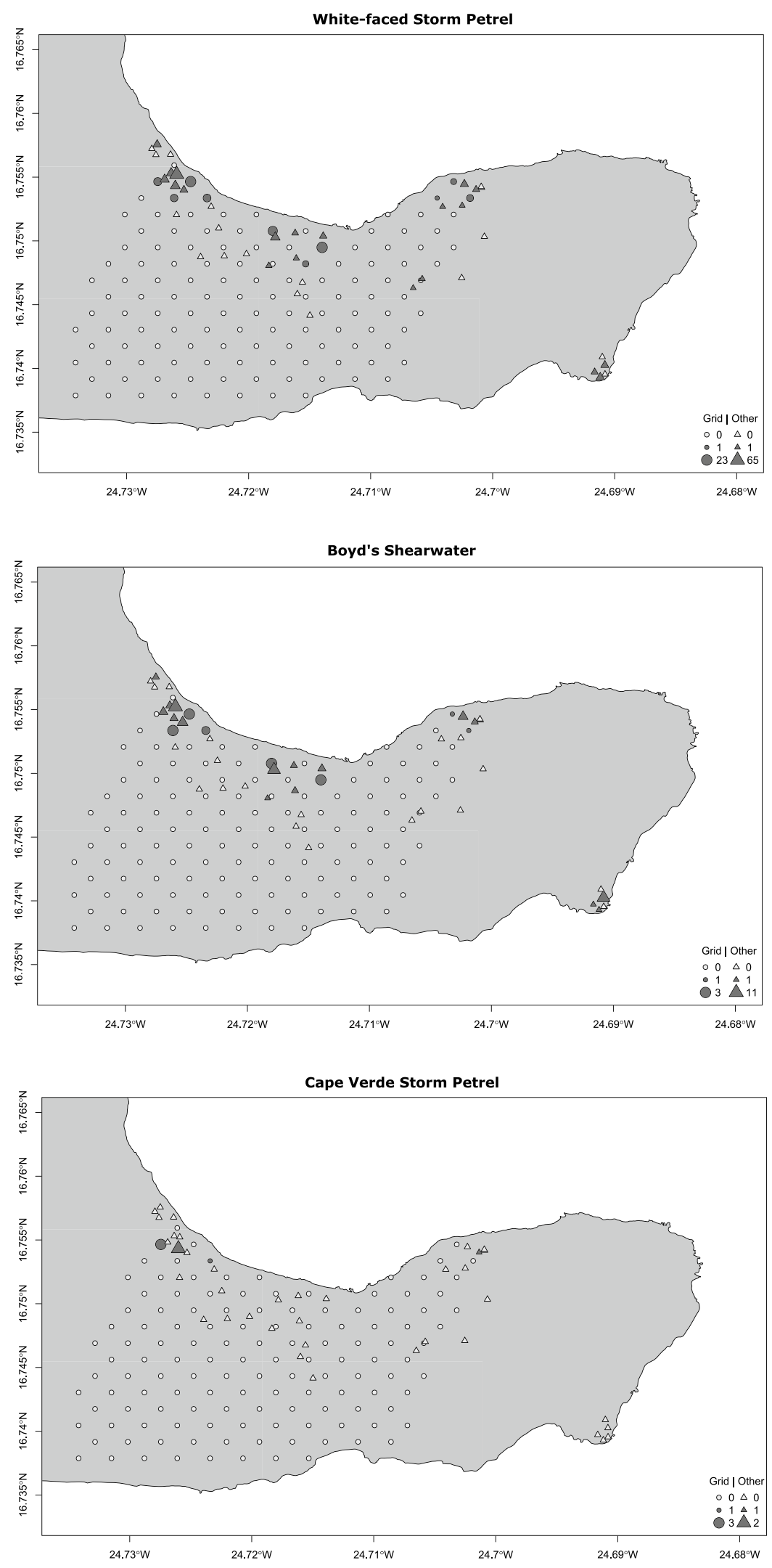
Table 1 Species abundance in terms of NISP (number of identified specimens) and MNI (minimum numbers of individuals) of each identified species from the bird bone assemblage collected from the Santa Luzia dunes

\begin{tabular}{|c|c|c|c|c|c|c|c|}
\hline Species & NISP & $\begin{array}{l}\text { Most abundant ana- } \\
\text { tomic element (NISP) }\end{array}$ & $\begin{array}{l}\text { 2nd most abundant } \\
\text { anatomic element } \\
\text { (NISP) }\end{array}$ & MNI & $\begin{array}{l}\text { MNI per point of occur- } \\
\text { rence (mean } \pm \mathrm{SD} \text {; range; } \\
N \text { ) }\end{array}$ & $\begin{array}{l}\text { FO }(\%) \\
(n=130 \\
\text { plots })\end{array}$ & $\begin{array}{l}\mathrm{NF}(\%) \\
(\mathrm{MNI} \\
\text { total =136) }\end{array}$ \\
\hline White-faced Storm Petrel & 378 & Tarsometatarsus (234) & Tibiotarsus (144) & 116 & $\begin{array}{l}11.6 \pm 7.40 \\
(1-23 ; 10)\end{array}$ & 7.7 & 85.3 \\
\hline Boyd's Shearwater & 25 & Humerus (22) & Tibiotarsus (3) & 16 & $\begin{array}{l}2.3 \pm 0.95 \\
(1-3 ; 7)\end{array}$ & 5.4 & 11.8 \\
\hline Cape Verde Storm Petrel & 7 & Humerus (5) & Tarsometatarsus (2) & 4 & $\begin{array}{l}2.0 \pm 1.41 \\
(1-3 ; 2)\end{array}$ & 1.5 & 2.9 \\
\hline
\end{tabular}

The frequency of occurrence (FO) is represented by the number of points in which a specific seabird species was found in relation to the total number of points. Numeric frequency (NF) is represented by the number of individuals of a species in relation to the total number of individuals found

upper limits of the $2 \sigma$ calibration interval extended out the calibration range. In addition, the lower limit of the $2 \sigma$ interval of nine of these samples fell inside the twentieth century, showing a recent extinction event for the colony. The estimated extinction year for the seabird colony was 1911, with a confidence interval 1910-1934 (95\% confidence). Due to the fact that we used the lower limits of the
$2 \sigma$ interval to retrieve this estimate, the extinction of the colony almost certainly occurred after 1911 . In addition, the analysis performed using $\mathrm{BCal}$ shows that the probability for year 1934 to be contained between the lower and upper temporal bounds of the dated samples (Table 2) was 0.78 , strongly suggesting that the seabird colony was still present during this year.
Table 2 Radiocarbon age (cal year B.P.-Before Present) and $2 \sigma$ calibration intervals (calibrated years Current Era-CE) of White-faced Storm Petrel and Boyd's Shearwater bones of Santa Luzia island

\begin{tabular}{|c|c|c|c|c|c|}
\hline Lab nr & Sample & Species & $\delta^{13} \mathrm{C}(\% \circ)$ & ${ }^{14} \mathrm{C}$ age (cal year B.P.) & $\begin{array}{l}2 \sigma \text { interval } \\
\text { Marine } 20 \\
\Delta \mathrm{R}=70 \pm 70\end{array}$ \\
\hline 210,930 & Tibiotarsus & White-faced Storm Petrel & -14.4 & $755 \pm 20$ & $1644-$ \\
\hline 210,931 & Tibiotarsus & White-faced Storm Petrel & -13.4 & $640 \pm 20$ & $1907-$ \\
\hline 210,932 & Tibiotarsus & White-faced Storm Petrel & -13.7 & $590 \pm 15$ & 1910- \\
\hline 210,933 & Tibiotarsus & White-faced Storm Petrel & -13.3 & $685 \pm 20$ & $1875-$ \\
\hline 210,934 & Tibiotarsus & White-faced Storm Petrel & -13.4 & $695 \pm 15$ & 1692 \\
\hline 210,935 & Tibiotarsus & White-faced Storm Petrel & -13.8 & $605 \pm 20$ & 1909- \\
\hline 210,936 & Tibiotarsus & White-faced Storm Petrel & -13.4 & $640 \pm 20$ & $1907-$ \\
\hline 210,937 & Tibiotarsus & White-faced Storm Petrel & -13.7 & $640 \pm 20$ & 1907 \\
\hline 210,938 & Tibiotarsus & White-faced Storm Petrel & -13.6 & $650 \pm 20$ & 1904- \\
\hline 210,939 & Tibiotarsus & White-faced Storm Petrel & -13.8 & $735 \pm 20$ & 1663- \\
\hline 222,706 & Humerus & Boyd's Shearwater & -13.3 & $850 \pm 15$ & $1520-1923$ \\
\hline 222,707 & Humerus & Boyd's Shearwater & -12.7 & $1470 \pm 15$ & $982-1334$ \\
\hline 224,285 & Humerus & Boyd's Shearwater & -13.0 & $980 \pm 15$ & $1426-1788$ \\
\hline 224,286 & Humerus & Boyd's Shearwater & -12.6 & $655 \pm 20$ & 1902- \\
\hline 224,287 & Humerus & Boyd's Shearwater & -12.2 & $580 \pm 15$ & 1910- \\
\hline 222,708 & Humerus & Boyd's Shearwater & -13.0 & $725 \pm 15$ & 1673- \\
\hline 222,709 & Humerus & Boyd's Shearwater & -13.1 & $705 \pm 15$ & 1686- \\
\hline 222,710 & Humerus & Boyd's Shearwater & -12.8 & $610 \pm 15$ & 1910- \\
\hline 222,711 & Humerus & Boyd's Shearwater & -12.8 & $730 \pm 15$ & $1669-$ \\
\hline 222,712 & Humerus & Boyd's Shearwater & -12.8 & $715 \pm 15$ & $1680-$ \\
\hline 224,288 & Humerus & Boyd's Shearwater & -12.6 & $1295 \pm 15$ & $1155-1479$ \\
\hline 224,289 & Humerus & Boyd's Shearwater & -12.7 & $1815 \pm 15$ & $644-1010$ \\
\hline 222,713 & Humerus & Boyd's Shearwater & -13.5 & $2160 \pm 15$ & $255-650$ \\
\hline
\end{tabular}

The $2 \sigma$ calibration intervals were calculated using software program OxCal v4.4, the Marine20 calibration curve and a regional correction of $\Delta \mathrm{R}=70 \pm 70$ 


\section{Discussion}

Our results provide the first insights into the extinct seabird populations of the island of Santa Luzia, Cabo Verde. The seabird remains found at the sampling area consisted of bones in the order of millions of individuals and represented five seabird species: White-faced Storm Petrel, Boyd's Shearwater, Cape Verde Storm Petrel, Cape Verde Shearwater and Pterodroma sp. The lower limits of $2 \sigma$ interval of several samples (Table 2 and Electronic Supplementary Information Fig. S1) provide evidence that this seabird colony persisted on the island at least until the beginning of the twentieth century. Elderly members of the local communities whom we interviewed, some of whom grew up on Santa Luzia, have no memory of seabirds on the island, supporting the idea that the extinctions happened before the mid-twentieth century.

The island of Santa Luzia was probably an important nesting locality for these species, especially for the Whitefaced Storm Petrel, given the very large estimated number of individuals. Our estimation of 4.6 million individuals encompasses at least three centuries of existence, which represents at least 15,000 birds dying per year. We can briefly speculate on the possible size of the colony, taking into account the individuals found within the study area (i.e., not considering those found at the supplementary points). Assuming an annual adult mortality rate of $8 \%$ (e.g. Beck and Brown 1972; Warham 1996; Schreiber and Burger 2001; Oro et al. 2005), and assuming that only a quarter of the mortality occurs at the colony (this is conservative, as very few small petrels are found dead in present-day colonies), 15,000 deaths per year would imply a living population at any moment of over 750,000 individuals. Many bones have probably by now been destroyed or washed away (most bones are relatively recent), so this estimate is likely conservative. Alternative simulations, with a progressively declining population due to cat predation give even higher estimates of the original population. Despite the massive uncertainties in these necessarily speculative calculations, there is little doubt that the colony at Santa Luzia was massive.

While the White-faced Storm Petrel is not currently present on Santa Luzia, it still breeds on Branco islet, ca. $10 \mathrm{~km}$ to the east (Hazevoet 1995; Vasconcelos et al. 2015), on Rombo (near Brava) and Pássaros (Boavista) and Laje Branca (Maio) islets (Hazevoet 2001; Semedo et al. 2020). Currently, the population of White-faced Storm Petrel in Cabo Verde is estimated at less than 10,000 pairs (Hazevoet 2010), two orders of magnitude smaller than our tentative estimate of the extinct population of Santa Luzia. White-faced Storm Petrels nest mostly in flat areas with sandy soil where they can excavate their burrows (Del
Hoyo et al. 1992). The population of White-faced Storm Petrels in Cabo Verde is particularly vulnerable due to the scarcity of available nesting habitat that is free of terrestrial introduced predators, further threatened by soil erosion, most likely limiting the size of the colonies of this species (all predator-free habitat is currently occupied). The small size and number of extant colonies make Whitefaced Storm Petrels extremely vulnerable to introduced predators and to anthropogenic threats such as disturbance by the trampling of burrows.

The extinct Boyd's Shearwater population, although possibly much smaller than that of the White-faced Storm Petrel, was still sizeable. For the same time period of 300 years, we found about one shearwater for every 10 White-faced Storm Petrels, and so the population might have consisted of tens of thousands of pairs. The current estimate of the population of this Cape Verde-endemic subspecies for the entire archipelago is ca. 5000 pairs (BirdLife International 2018) and this species is thought to have bred on most of the islands and islets of Cabo Verde (Hazevoet 1995; Semedo et al. 2020). Currently, the main colonies are located on Raso, Branco and Cima islets. Although Boyd's Shearwater may nest in burrows similar to those of the White-faced Storm Petrel, as they do on the islets of Rombo, the preferred breeding habitat include crevices in cliffs and burrows under rocks, at different altitudes.

The Cape Verde Storm Petrel is endemic to Cabo Verde and is known to breed on the islets of Cima (one of the Rombo islets), Branco, Raso and possibly on the islets of Pássaros and Curral Velho, both off Boa Vista (Hazevoet 1995) as well as along the coasts of some of the main islands (Hazevoet 1994, 1995). Cape Verde Storm Petrels breed in crevices in cliff holes and burrows under rocks. However, on Cima, Branco and Pássaros islets they also nest in burrows among White-faced Storm Petrels (Semedo et al. 2020). In our study, the Cape Verde Storm Petrel was the species that occurred least frequently. However, it seems to be the only one of the three still breeding on Santa Luzia, with breeding records from a small area of inaccessible cliffs sites where they are likely protected from the population of cats on the island, which would otherwise likely drive them to extinction (Oliveira et al. 2013; Semedo et al. 2020). Moreover, the species also persists in some of the main inhabited islands with cats and rats, such as Santo Antão, probably in equally inaccessible sites (Semedo et al. 2020). Despite the lack of census data, the restricted distribution of the current Cape Verde Storm Petrel population on Santa Luzia suggests that it is only a small remnant of the one which once existed on this island.

The endemic Cape Verde Shearwater and possibly Cape Verde Petrel were found in the supplementary points, and we were not able to estimate the number of individuals. Cape Verde Shearwater has a wide distribution in the archipelago, 
generally occurring near the coast at low-elevation areas, but at lower densities on populated islands (Semedo et al. 2020). For a long time (probably several centuries), the species has been exploited by humans for food and bait, especially at its main breeding colonies (i.e., Raso and Branso Islets). In contrast, Cape Verde Petrel occurs only on mountainous sites, from mid-to-high elevations, on Santo Antão, São Nicolau, Santiago and Fogo islands (Semedo et al. 2020). Cape Verde Petrels have been harvested by local people and predated by cats for centuries, threats which persist today. Indeed, a recent study on Fogo Island shows that this species was the bird most frequently consumed by feral cats (Medina et al. 2010).

At the time of the archipelago's colonization, the seabird colony on Santa Luzia was probably massive, as the subfossil remains indicate. However, our data suggest that these seabird populations went extinct in a relatively short period of time. In contrast, the populations on neighboring islands (Branco and Raso) persisted, suggesting that seabird extinctions on Santa Luzia were driven by threats occurring at the colony rather than at sea, as the latter would have affected neighboring colonies too.

On some islands and islets throughout the Cabo Verde archipelago, seabirds have become totally extinct due to the combined predation by humans and alien mammals (Hazevoet 1994; Semedo et al. 2020). Due to the lack of natural resources and inclement conditions for agriculture on Cabo Verde (Caniato and Naurois 2006), seabirds are known to have been hunted by settlers (de Naurois 1969), resulting in the decline of seabird populations in the archipelago (Murphy 1924; Hazevoet 1995). Nonetheless, the seabird remains found in Santa Luzia showed no sign of poaching. On the most populated islands of Cabo Verde, seabirds are mainly found in areas almost inaccessible to humans (Semedo et al. 2020).

The effect of the introduction of alien mammals to oceanic island species is dramatic and well documented (e.g. Worthy and Holdaway 2002; Steadman 2006). The house mouse (Mus musculus) occurs on all inhabited islands of Cabo Verde, although there are no records on the presence of this species on the uninhabited islands, except on Santa Luzia Island (Hazevoet and Masseti 2011; Semedo et al. 2020) and Rombo islets (Semedo et al. 2020). Currently, house mice have a widespread distribution but a low abundance on Santa Luzia Island, appearing to be particularly associated with fishermen camps (Geraldes et al. 2016). Although general abundance on the island is low, house mice densities show fluctuations and may be very high at times (unpublished data). In general, house mice are not considered as an important threat to seabirds (Burger and Gochfeld 1994; Campos and Granadeiro 1999; Angel et al. 2009; Dias et al. 2019) despite notable exceptions (Jones et al. 2019), and are unlikely to have been the cause of the demise of seabirds on Santa Luzia.

Examples of seabird extinctions caused directly by goats are scarce. However, goats are known to impact burrowing petrels, due to the depletion of vegetation cover and subsequent soil erosion (Bell 1995). In Cabo Verde, the presence of goats altered the natural habitat of Grande Islet, the largest of the Rombo Islets, known for housing large colonies of seabirds in the past (Murphy 1924). Goats are no longer present on Santa Luzia Island.

Domestic cats are one of the major threats to seabirds throughout the world (Moors and Atkinson 1984; Burger and Gochfeld 1994; Medina et al. 2011), even when other invasive species are present (Courchamp et al. 2003; Hervías et al. 2013). On Santa Luzia, this invasive predator is considered as one of the main threats to native endangered species, as such, it is likely that cats played a decisive role in the extinction of seabirds on Santa Luzia, which is also supported by their present predatory role which forces the confinement of Cape Verde Storm Petrel to inaccessible places on this island (Oliveira et al. 2013).

In the recent past, other local extinctions have occurred on Santa Luzia, such as the endemic Cape Verde giant skink Chioninia coctei (Duméril and Bibron 1839), declared extinct at the beginning of the twentieth century (Mateo 2012; Schleich 1996). The causes of its extinction may have included over-collection, and predation by feral cats (Andreone 2000). This species was largely dependent on seabird colonies, feeding on eggs and chicks (Bocage 1896; Mateo 2012), and the disappearance of these seabird colonies may also have contributed to its extinction. Recently, Medina et al. (2020) showed that on Santa Luzia, feral cats have also turned out to be a serious threat to reptiles, which represent more than $70 \%$ of their diet (in terms of consumed biomass).

During the last few years, a program for the eradication of feral cats has been implemented on Santa Luzia Island. To date, a total of 131 feral cats have already been eliminated, leading to a current population estimate close to zero (Martinez et al. 2021). By removing the threat of the invasive species, efforts to re-establish extirpated species can be undertaken (Bellingham et al. 2010; Kappes and Jones 2014), such as for the critically endangered Raso lark, Alauda razae recently re-established on Santa Luzia by a translocation program (Brooke et al. 2020). The feral cat eradication program appears to be producing good results for the native species, such as the Bar-tailed Lark Ammomanes cinctura, the Cream-colored Courser Cursorius cursor and, the Common Quail Coturnix coturnix which are now common throughout the island (contrasting with their rarity at the beginning of the project) (BirdLife International 2020). Also, the terrestrial herpetofauna (geckos and skinks) 
appears to have increased and many juveniles are regularly observed throughoutthe island (Brooke et al. 2020).

Santa Luzia is the largest island in the Marine Protected Area (MPA) composed of three islands (Santa Luzia, Raso and Branco) and the surrounding sea, and it has the greatest potential to provide significant additional habitat for seabird species (Geraldes et al. 2016). The sub-fossil evidence in this study confirmed the presence of several seabird species in the past, several of which still nest on nearby islands (Geraldes et al. 2016; Semedo et al. 2020). After the eradication of cats, recolonization of Santa Luzia by seabirds could take place naturally or be assisted by reintroduction programs. Passive recovery of seabirds may not easily occur for islands $>25 \mathrm{~km}$ from source populations (Kappes and Jones 2014; Buxton et al. 2014). Although, Santa Luzia is less than $8 \mathrm{~km}$ from potential source populations of seabirds, natural recolonizations are known to occur extremely slowly due to the philopatric character of many seabird species (Bellingham et al 2010; Buxton et al. 2014). Further research should aim at improving our knowledge on potential breeding areas for seabirds on Santa Luzia and evaluating the seabird colonies on the nearby islands as possible source populations for future re-introduction projects. This action will only be possible if the complete removal of feral cats from the island is successful. Consistent and effective monitoring plans should be an integral component of a future seabird restoration project on Santa Luzia.

\section{Conclusion}

In conclusion, our study demonstrates that Santa Luzia was once an important nesting site for three seabird species, especially for White-faced Storm Petrel. In the past, Santa Luzia may have hosted the largest White-faced Storm Petrel and Boyd's Shearwater colonies in the entire Cabo Verde archipelago. The introduction of alien species, particularly cats, together with direct human predation and disturbance arising from the colonization of Santa Luzia are the likely drivers of the extinction of this seabird colony. The nearest islets of Raso and Branco-neither of which has ever been inhabited-still maintain important populations of seabirds, which is in support for our hypothesis. Santa Luzia has a great potential to provide significant additional habitat for these species, once the current threats are removed. The strong declines in feral cat numbers already lead to an increase in the number of birds detected while prospecting for nests (Cape Verde Shearwater calls regularly recorded and Boyd's Shearwater detected in burrows on the ground) (unpublished data). The complete removal of cats would represent an important step to the recolonization of the island by the seabird species that once occurred there.
Supplementary Information The online version contains supplementary material available at https://doi.org/10.1007/s10336-021-01923-8.

Acknowledgements This work received logistic support from the project Desertas-Sustainable Management of Santa Luzia Marine Reserve, coordinated by SPEA, Biosfera 1 and DNA (Cabo Verde Environmental Agency) and funded by the MAVA Foundation pour la nature (MAVA 15101). Special thanks go to the NGO Biosfera I for providing travel, subsistence, and accommodation during fieldwork. Moreover, thanks are due to all members of Biosfera Santa Luzia camp whom assisted fieldwork. We also thank the valuable help given by Carlos Pimenta for assistance with bone identification and Monge Soares for the help with radiocarbon data.

Author contributions Methodology, MA, PC, JPG and JCR; Investigation, MA; Formal analysis, MA, JPG and JCR; Writing — original draft, MA; Writing - review and editing, MA, PC, JPG, JCR and PG; Supervision, PC and JPG. All authors read and approved the final manuscript.

Funding This study was financial supported by CESAM (UIDB/50017/2020 and UIDP/50017/2020), MARE (UIDB/04292/2020 and UIDP/04292/2020) and doctoral grant SFRH/ BD/133561/2017 awarded to MA, provided by the Foundation for Science and Technology (FCT; Portugal).

Data availability The datasets generated during and/or analyzed during the current study are available from the corresponding author on reasonable request.

Code availability Not applicable.

\section{Declarations}

Conflict of interest Authors declare no conflicts of interests.

Ethical approval The work reported in this paper comply with the standards and procedures laid down by the Cape Verde legislation.

Consent to participate All authors agreed with the content and all gave explicit consent to submit.

Consent for publication All authors gave explicit consent to publish.

\section{References}

Alcover JA, McMinn M (1995) Fossil birds from the Canary Islands. Cour Forschungsinst Senckenberg 181:207-213

Andreone F (2000) Herpetological observations on Cape Verde: a tribute to the Italian naturalist Leonardo Fea, with complementary notes on Macroscincus coctei (Duméril \& Bibron, 1839) (Squamata: Scincidae). Herpetozoa 13:15-26

Angel A, Wanless RM, Cooper J (2009) Review of impacts of the introduced house mouse on islands in the Southern Ocean: are mice equivalent to rats? Biol Invasions 11:1743-1754. https://doi. org/10.1007/s10530-008-9401-4

Barnosky AD, Hadly EA, Gonzalez P, Head J, Polly PD, Lawing AM, Eronen JT, Ackerly DD, Alex K, Biber E, Blois J, Brashares J, Ceballos G, Davis E, Dietl GP, Dirzo R, Doremus H, Fortelius M, Greene HW, Hellmann J, Hickler T, Jackson ST, Kemp M, Koch PL, Kremen C, Lindsey EL, Looy C, Marshall CR, Mendenhall C, 
Mulch A, Mychajliw AM, Nowak C, Ramakrishnan U, Schnitzler J, Das Shrestha K, Solari K, Stegner L, Stegner MA, Stenseth NC, Wake MH, Zhang Z (2017) Merging paleobiology with conservation biology to guide the future of terrestrial ecosystems. Science 10:355. https://doi.org/10.1126/science.aah4787

Bebiano JB (1932) A Geologia do Arquipélago de Cabo Verde. Departamento das Comunidades dos Serviços Geológicos de Portugal, Lisboa

Beck JR, Brown DW (1972) The biology of Wilson's Storm petrel, Oceanites oceanicus (Kuhl), at Signey Island, South Orkney Islands. Br Antarct Surv Sci Rep 69:54

Bell BD (1995) The effects of goats and rabbits on breeding seabirds: methods of eradication and control. Bol Mus Munic Funchal 4:83-89

Bellingham P, Towns D, Cameron E, Davis J, Wardle D, Wilmshurst J, Mulder C (2010) New Zealand island restoration: seabirds, predators, and the importance of history. N Z J Ecol 34(1):115

Belopol'skii LO (1957) Ecology of sea colony birds of the Barents Sea. Published for the Israel Program for Scientific Translations pursuant to an agreement with the National Science Foundation and the Smithsonian Institution, Washington, DC, p 346

BirdLife International (2018) State of the world's birds: taking the pulse of the planet. BirdLife International, Cambridge

BirdLife International (2020) Critically Endangered lark rebounds after reintroduction success. https://www.birdlife.org/europe-and-centr al-asia/news/critically-endangered-lark-rebounds-after-reintroduc tion-success. Accessed 1 June 2021

Blackburn TM, Cassey P, Duncan RP, Evans KL, Gaston KJ (2004) Avian extinction and mammalian introductions on oceanic islands. Science 305:1955-1958. https://doi.org/10.1126/science.1101617

Bocage JV (1896) Reptis de algumas possessões portuguezas d'Africa que existem no museu de Lisboa. Jornal de Sciencias Mathematicas, Physicas e Naturaes. Segunda Série IV, 65-104

Boessneck J, Kinzelbach R (1993) Ein prähistorischer brutplatz von seevögeln auf er insel Sal (Kapverden). J Ornithol 134:245-271

Bronk Ramsey C (2009) Bayesian analysis of radiocarbon dates. Radiocarbon 51(1):337-360. https://doi.org/10.1017/S00338222000338 65

Brooke M, Gregory L, Geraldes P, Castelló L, Donald P, Melo T, Bores J (2020) Lessons and surprises from an inter-island re-introduction of the critically endangered Raso Lark Alauda razae of Cape Verde. PARKS. https://doi.org/10.2305/IUCN.CH.2020.PARKS26-2MB.en

Brown TA, Nelson DE, Vogel JS, Southon JR (1988) Improved collagen extraction by modified Longin method. Radiocarbon 30(2):171-177. https://doi.org/10.1017/S0033822200044118

Buck C, Bard E (2007) A calendar chronology for Pleistocene mammoth and horse extinction in North America based on Bayesian radiocarbon calibration. Quat Sci Rev 26:2031-2035. https://doi. org/10.1016/j.quascirev.2007.06.013

Buck CE, Christen JA, James GN (1999) BCal: an on-line Bayesian radiocarbon calibration tool. Internet Archaeology 7. http://intar ch.ac.u/ourna/ssue/uck/. Accessed 10 Oct 2020

Burger J, Gochfeld M (1994) Predation and effects of humans on island-nesting seabirds. In: Nettleship DN, Burger J, Gochfeld M (eds) Seabirds on Island: threats, case studies and action plans. BirdLife International, Cambridge, pp 39-67

Buxton R, Jones C, Moller H, Towns D (2014) Drivers of seabird population recovery on New Zealand Islands after predator eradication. Conserv Biol. https://doi.org/10.1111/cobi.12228

Campos AR, Granadeiro JP (1999) Breeding Biology of the Whitefaced Storm-Petrel on Selvagem Grande Island, North-East Atlantic. Waterbirds 22:199-206. https://doi.org/10.2307/1522208

Caniato B, Naurois J (2006) Cabo Verde: a fome em sua literatura. Veredas 7:131-214
Clements C (2013) sExtinct: Calculates the historic date of extinction given a series of sighting events. R package version 1.1. https:// CRAN.R-project.org/package $=$ sExtinct. Accessed 5 June 2020

Clements CF, Worsfold N, Warren P, Collen B, Blackburn T, Clark N, Petchey OL (2013) Experimentally testing an extinction estimator: solow's optimal linear estimation model. J Anim Ecol 82:345354. https://doi.org/10.1111/1365-2656.12005

Costa AF (1939) Cartas das ilhas de Cabo Verde de Valentim Fernandes (1506-1508). Agência Geral das Colónias, Lisboa

Courchamp F, Chapuis JL, Pascal M (2003) Mammal invaders on islands: impact, control and control impact. Biol Rev 78:347-383. https://doi.org/10.1017/S1464793102006061

Crowley PH (1992) Resampling methods for computation-intensive data analysis in ecology and evolution. Annu Rev Ecol Evol Syst 23:405-447. https://doi.org/10.1146/annurev.es.23.110192. 002201

Croxall JP, Prince PA (1980) Food, feeding ecology and ecological segregation of seabirds at South Georgia. Biol J Linn Soc 14:103131. https://doi.org/10.1111/j.1095-8312.1980.tb00101.x

Croxall JP, Butchart SHM, Lascelles B et al (2012) Seabird conservation status, threats and priority actions: a global assessment. Bird Conserv Int 22:1-34. https://doi.org/10.1017/S095927091 2000020

de Naurois R (1969) Notes brèves sur l'Archipel du Cap-Vert. Faunistique, endémisme, écologie. Bull Inst Fond Afr Noire 31:143-218

Del Hoyo J, Elliott A, Sargatal J (1992) Handbook of the birds of the world. Lynx Edicions, Barcelona

Dias MP, Martin R, Pearmain EJ, Burfield IJ, Small C, Phillips RA, Croxall JP (2019) Threats to seabirds: a global assessment. Biol Conserv 237:525-537. https://doi.org/10.1016/j.biocon.2019.06. 033

Diniz AC, Matos GC (1994) Carta de zonagem agro-ecológica e da vegetação de Cabo Verde. VII-Ilha de Santa Luzia. Garcia De Orta, Série Botânica 12:101-119

Duméril C, Bibron G (1839) Erpétologie Générale; Histoire Complète des Reptiles, Tome cinquième. Librairie Encyclopédique de Roret, Paris. https://doi.org/10.5962/bhl.title.45973

Efron B, Gong G (1983) A leisurely look at the bootstrap, the jackknife, and cross validation. Am Stat 37:36-48

Geraldes P, Kelly J, Melo T, Donald P (2016) The Restoration of Santa Luzia, Republic of Cabo Verde, Feasibility Study and Restoration action plan 2016-2020. Protecting Threatened and Endemic Species in Cape Verde: A Major Island Restoration Project (CEPF). Sociedade Portuguesa para o Estudo das Aves

Hazevoet CJ (1994) Status and conservation of seabirds in the Cape Verde Islands. In: Nettleship DN, Burger J, Gochfeld M (eds) Seabirds on islands: threats, case studies and action plans. BirdLife International, Cambridge, pp 279-293 (BirdLife Conservation Series no. 1)

Hazevoet CJ (1995) The birds of the Cape Verde Islands. British Ornithologists Union, London, p 192 (BOU check List No. 13)

Hazevoet CJ (2001) Cape Verde. In: Fishpool LDC, Evans MI (eds) Important bird areas in Africa and associated islands. Pisces Publications, Newbury, pp 161-168

Hazevoet CJ (2010) Sixth report on birds from the Cape Verde Islands, including records of 25 taxa new to the archipelago. Zoologia Cabovediana 1:3-44

Hazevoet CJ, Masseti M (2011) On the history of the green monkey Chlorocebus sabaeus (L., 1766) in the Cape Verde Islands, with notes on other introduced mammals. Zoologia Caboverdiana 2:12-24

Heaton T, Köhler P, Butzin M, Bard E, Reimer R, Austin W, Bronk Ramsey C, Grootes P, Hughen K, Kromer B, Reimer P, Adkins J, Burke A, Cook M, Olsen J, Skinner L (2020) Marine20 the marine radiocarbon age calibration curve $(0-55,000 \mathrm{cal} \mathrm{BP})$. Radiocarbon 62:779-820. https://doi.org/10.1017/RDC.2020.68 
Hervías S, Henriques A, Oliveira N, Pipa T, Cowen H, Ramos JA, Nogales M, Geraldes P, Silva C, Ruiz de Ybáñez R, Oppel S (2013) Studying the effects of multiple invasive mammals on Cory's shearwater nest survival. Biol Invasions 15:143-155. https://doi.org/10.1007/s10530-012-0274-1

Hunter I, Croxall JP, Prince PA (1982) The distribution and abundance of burrowing seabirds (Procellariiformes) at Bird Island, South Georgia. Brit Antarct Surv B 56:49-68

Jones CW, Risi MM, Cleeland J, Ryan PG (2019) First evidence of mouse attacks on adult albatrosses and petrels breeding on subAntarctic Marion and Gough Islands. Polar Biol 42:619-623. https://doi.org/10.1007/s00300-018-02444-6

Kappes P, Jones H (2014) Integrating seabird restoration and mammal eradication programs on islands to maximize conservation gains. Biodivers Conserv. https://doi.org/10.1007/s10531-013-0608-z

Longin R (1971) New method of collagen extraction for radiocarbon dating. Nature 230:241-242. https://doi.org/10.1038/230241a0

Martinez J, Delgado A, Ferreira M, Bores J, Geraldes P (2021) Metodologia e resultados, Erradicação de gatos ferais na Ilha de Santa Luzia. Projeto Desertas-Sustainble Management of Santa Luzia Marine Reserve, financiado por MAVA Foundation. Sociedade Portuguesa para o Estudo das Aves, Lisboa

Mateo JA (2012) Las trágicas crónicas de la lisa gigante de Cabo Verde. Makaronesia, Boletín de la Asociación Amigos del Museo de la Naturaleza y el Hombre (Santa Cruz de Tenerife). 14: 2-14

McMinn M, Jaume D, Alcover JA (1990) Puffinus olsoni n.sp. nova espècie de baldritja recentment extingida provinent de depòsits espeleològics de Fuerteventura i Lanzarote (Illes Canàries, Atlàntic Oriental). Endins 16:63-71

Medina FM, Oliveira P, Menezes D, Teixeira S, García R, Nogales M (2010) Trophic habits of feral cats in the high mountain shrublands of the Macaronesian islands (NW Africa, Atlantic Ocean). Acta Theril 55:241-250. https://doi.org/10.4098/j.at.0001-7051.069.2009

Medina FM, Bonnaud E, Vidal E, Tershy BR, Zavaleta ES, Donlan CJ, Keitt BS, Le Corre M, Horwath SV, Nogales M (2011) A global review of the impacts of invasive cats on island endangered vertebrates. Glob Chang Biol 17:3503-3510. https://doi.org/10.1111/j. 1365-2486.2011.02464.x

Medina FM, Melo T, Oliveira P, Nogales M, Geraldes P (2020) Trophic ecology of an introduced top predator (Felis catus) on a small African oceanic islet (Santa Luzia, Cabo Verde Islands). Afr J Ecol. https://doi.org/10.1111/aje.12800

Monge Soares AM, Matos Martins JM, Cardoso JL (2011) Marine radiocarbon reservoir effect of coastal waters off Cape Verde Archipelago. Radiocarbon 53(2):289-296. https://doi.org/10.1017/S0033 822200056551

Monteiro LR, Ramos JA, Furness RW (1996) Past and present status and conservation of the seabirds breeding in the Azores archipelago. Biol Conserv 78:319-328. https://doi.org/10.1016/S0006-3207(96) 00037-7

Moors PJ, Atkinson IAE (1984) Predation on seabirds by introduced animals, and factors affecting its severity. In: Moors PJ (ed) Conservation of island birds: case studies for the management of threatened island birds. International Council for Bird Preservatio, Cambridge, pp 667-690

Murphy RC (1924) The marine ornithology of the Cape Verde Islands, with a list of all the birds of the archipelago. Bull Am Mus Nat Hist 50:211-278

Oliveira N, Oliveira J, Melo T, Melo J, Geraldes P (2013) Possible breeding of Cape Verde storm-petrel oceanodroma jabejabe (Bocage, 1875) on Santa Luzia, Cape Verde Islands. Zoologia CaboVerdiana 4:17-20

Olson S, James H (1982) Fossil birds from the Hawaiian Islands: evidence for wholesale extinction by man before Western contact. Science 217:633. https://doi.org/10.1126/science.217.4560.633
Oro D, de León A, Minguez E, Furness RW (2005) Estimating predation on breeding European storm-petrels (Hydrobates pelagicus) by yellow-legged gulls (Larus michahellis). J Zool 265:421-429. https://doi.org/10.1017/S0952836905006515

Pearson TH (1968) The feeding biology of seabird species breeding on the Fame Islands, Northumberland. J Anim Ecol 37:521-552. https://doi.org/10.2307/3073

Pieper H (1985) The fossil land birds of Madeira and Porto Santo. Bocagiana $88: 1-6$

Quammen D (1996) The song of the Dodo: Island biogeography in an age of extinctions. Pimlico, London. https://doi.org/10.1093/isle/4.1.138

R Core Team (2020) R: A language and environment for statistical computing. R Foundation for Statistical Computing, Vienna, Austria. http://www.r-project.org/index.html

Ramis D, Alcover JA, Coll J, Trias M (2002) The chronology of the first settlement of the Balearic Islands. J Mediterr Archaeol 15:3-24. https://doi.org/10.1558/jmea.v15i1.3

Rando JC (2002) New data of fossil birds from El Hierro (Canary Islands): probable causes of extinction and some biogeographical considerations. Ardeola 49:39-49

Rando JC, Alcover JA (2008) Evidence for a second western Palaearctic seabird extinction during the last millennium: the Lava Shearwater Puffinus olsoni. Ibis 150:188-192. https://doi.org/10.1111/j.1474919X.2007.00741.x

Rando JC, Alcover JA (2010) On the extinction of the Dune Shearwater (Puffinus holeae) from the Canary Islands. J Ornithol 151:365-369. https://doi.org/10.1007/s10336-009-0463-6

Roberts DL, Solow AR (2003) Flightless birds: when did the dodo become extinct? Nature 426:245. https://doi.org/10.1038/426245a

Schleich HH (1996) Lista vermelha para os répteis (Reptilia). In: Leyens T, Lobin W (eds) Primeira Lista Vermelha de Cabo Verde. Frankfurt, pp 122-125

Schreiber EA, Burger J (2001) Biology of Marine Birds. CRC Press, Boca Raton

Scofield RP (2009) Procellariiform extinctions in the Holocene: threat processes and wider ecosystem-level implications. In: Turvey ST (ed) Holocene Extinctions. Oxford University Press, Oxford, pp 151-166. https://doi.org/10.1093/acprof:oso/9780199535095.003. 0007

Semedo G, Paiva V, Militão T, Rodrigues I, Dinis H, Pereira J, Matos D, Ceia F, Almeida N, Geraldes P, Saldanha S, Barbosa N, HernándezMontero M, Fernandes C, González-Sólis J, Ramos J (2020) Distribution, abundance, and on-land threats to Cabo Verde seabirds. Bird Conserv Int. https://doi.org/10.1017/S0959270920000428

Solow AR (2005) Inferring extinction from a sighting record. Math Biosci 195:47-55. https://doi.org/10.1016/j.mbs.2005.02.001

Steadman D (2006) Extinction and biogeography of tropical pacific birds. Integrative and comparative biology. University of Chicago Press, Chicago, pp 790-793. https://doi.org/10.1093/icb/icm013

Steadman DW, Olson SL (1985) Bird remains from an archaeological site on Henderson Island, South Pacific: man caused extinctions on an "uninhabited" island. Proc Natl Acad Sci USA 82:6191-6195. https://doi.org/10.1073/pnas.82.18.6191

Stuiver M, Braziunas TF (1993) Modeling atmospheric 14C influences and $14 \mathrm{C}$ ages of marine samples to $10,000 \mathrm{BC}$. Radiocarbon 35:137-189. https://doi.org/10.1017/S0033822200013874

Tyrberg T (2009) Holocene avian extinctions. In: Turvey ST (ed) Holocene extinctions. Oxford University, Oxford, pp 63-106

Vasconcelos R, Freitas R, Hazevoet CJ (2015) História Natural das Ilhas Desertas-Santa Luzia, Branco e Raso. Sociedade Caboverdiana de Zoologia, 1: 307. https://doi.org/10.13140/RG.2.1.2371.3362

Verlinden C (1963) António de Noli e a colonização das ilhas de Cabo Verde. Revista Da Faculdade De Letras Da Universidade De Lisboa 7:28-45

Walker CA, Wragg GM, Harrison CJO (1990) A new shearwater from the Pleistocene of the Canary Islands and its bearing on the evolution of 
certain Puffinus shearwaters. Hist Biol 3:203-224. https://doi.org/ 10.1080/08912969009386522

Warham J (1996) The behaviour, population biology and physiology of the petrels. Academic Press, London

Warheit KI (2002) The seabird fossil record and the role of paleontology in understanding seabird community structure. In: Schreiber EA, Burger J (eds) Biology of marine birds. CRC Press, Boca Raton, pp 17-55. https://doi.org/10.1201/9781420036305

Wood JR, Alcover JA, Blackburn TM, Bover P, Duncan RP, Hume JP, Louys J, Meijer HJ, Rando JC, Wilmshurst JM (2017) Island extinctions: processes, patterns, and potential for ecosystem restoration. Environ Conserv 44(4):348-358. https://doi.org/10. 1017/S037689291700039X

Worthy TH, Holdaway RN (2002) The Lost world of the moa: prehistoric life of New Zealand. Indiana University Press, Bloomington

Zilhão J (2001) Radiocarbon evidence for maritime pioneer colonization at the origins of farming in west Mediterranean Europe. Proc Natl Acad Sci USA 98:14180-14185. https://doi.org/10.1073/pnas. 241522898

Publisher's Note Springer Nature remains neutral with regard to jurisdictional claims in published maps and institutional affiliations. 